\title{
A Review on the Book Series Compendium of Sources on Chinese Science and Technology
}

\section{ZHENG Cheng 郑诚}

(Institute for the History of Natural Sciences, Chinese Academy of Sciences, Beijing 100190, China)

Review of Ren, Jiyu 任继愈, ed. [1993-1995] 2015. Zhongguo kexue jishu dianji tonghui 中国科学技 术典籍通汇 [Compendium of Sources on Chinese Science and Technology]. Zhengzhou: Elephant Press.

Drimary sources are the prerequisite for exploring the history of science and 1 technology in pre-modern China. How can the valuable ones be winnowed out from the vast landscape of historical materials?

Books predominate among Chinese historical sources. Guji 古籍, or pre-modern Chinese books are generally defined as pre-1912 printed books and manuscripts, often bound in the characteristic traditional Chinese way. The General Catalogue of Pre-modern Chinese Books (Zhongguo guji zongmu 中国古籍总目) encompasses around 200,000 titles, and is estimated to cover more than 500,000 editions (Compilation Committee 2012, "Preface," 3). From at least the 1980s, almost all the printed books and manuscripts prior to the year of 1796 were categorized as rare books. ${ }^{2}$ The Union Catalogue of Rare Books in China (Zhongguo guji shanben shumu 中 国古籍善本书目) contains approximately 74,000 editions (Editorial Committee 19891998).

From the rise of printing in the eighth century until the mid-nineteenth century, most Chinese printed books were wood-block editions, with a small portion (less than $1 \%$ ) being movable-type editions. There are only a few extant copies for many editions, and some are even unique copies, making direct access inconvenient, especially the

Received: January 29, 2021. Revised: April 10, 2021.

This review was translated into English by Lü Xin 吕昕, and copyedited by John Moffett.

1 Research interests: History of S\&T in Ming and Qing China, history of military technology. Email: zhengcheng@ihns.ac.cn

2 A large number of printed books and manuscripts between 1796 and 1911 are also treated as rare books based on their degree of rarity. 
very rare ones. Nowadays, in addition to new critical editions and full-text databases, facsimile editions and databases of digital images are usually employed for research purposes.

During the period from 1949 to 2010, particularly from 1980 onwards, over 450 new facsimile series of pre-modern Chinese books were published on the Chinese mainland, amounting to about 50,000 titles of various texts (Nan 2012). The Siku series of facsimile reprints (1986-2005) totals over 7000 volumes, and includes facsimile reprints of more than 15,000 titles, serving as the paramount massive collection of Chinese scholarship from antiquity to 1911 (Wu 2016, 1).

Roughly speaking, more than 12,000 titles are of direct relevance to science and technology, accounting for about $6 \%$ of pre-modern Chinese books. The subjects of these titles are concerned with such fields as astronomy/calendrical science/astrology, mathematics, agriculture, medicine, geography, water engineering, natural history, and various practical techniques, as well as books of "New Learning" that arose in great numbers after the 1850s and introduced scientific and technological knowledge from the West. Medical titles amount to nearly half of this total. Since 1949, new editions of about 2000 titles in science and technology have been published, most of which are facsimile reprints (Sun 2017).

The Compendium of Sources on Chinese Science and Technology (Zhongguo kexue jishu dianji tonghui 中国科学技术典籍通汇, hereafter CS), reprinted in 2015, is to date the largest facsimile series of pre-modern Chinese books of science and technology. The compilation of the CS was led by the Institute for the History of Natural Sciences (IHNS), Chinese Academy of Sciences (CAS), and was first published between 1993 and 1995 by Henan Education Press (renamed Elephant Press in 1996). It consists of ten parts divided into such subjects as mathematics, astronomy, agriculture, and medicine, and a general index, totaling 50 hardcover volumes, 541 titles, and 40 million characters. ${ }^{3}$ Most titles included (with a few exceptions) are no later than the mid-nineteenth century when China was heavily impacted by the West, and form a systematic assemblage of works. The CS remains a fundamental collection of historical materials for researching science and technology in traditional China. In the mid-1990s, when such historical materials were difficult to locate, the CS provided a great quantity of first-hand information that served rather like a professional library, and was warmly received by the academic community. In 1997, the CS won the Honorable Mention of the Chinese National Book Award.

3 Each volume is mostly between nine hundred to fifteen hundred pages, and each page generally presents two folios (viz. four pages) of the original book. 


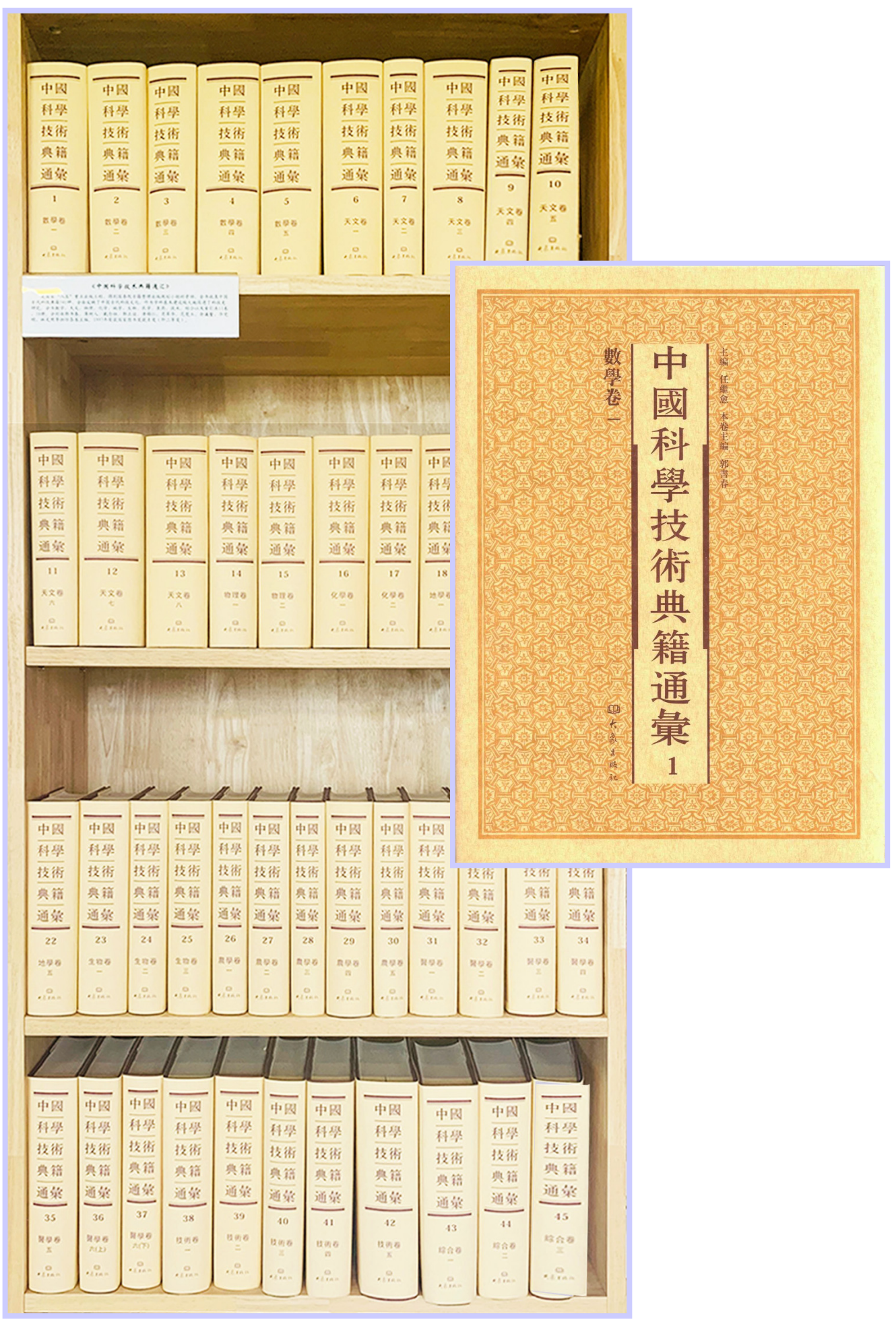

Figure 1: Compendium of Sources on Chinese Science and Technology (2015). 
The book series can be summarized as follows: ${ }^{4}$

Table 1: A summary of the $C S$ book series

\begin{tabular}{rccccc}
\hline & Parts & Number of volumes & Number of titles & Chief editor & Year \\
\hline 1 & Mathematics & 5 & 90 & Guo Shuchun & 1993 \\
2 & Astronomy & 8 & 82 & Bo Shuren & 1993 \\
3 & Biology & 3 & 42 & Gou Cuihua & 1993 \\
4 & Agriculture & 5 & 43 & Fan Chuyu & 1994 \\
5 & Medicine & 7 & 26 & Yu Ying'ao & 1994 \\
6 & Technology & 5 & 73 & Hua Jueming & 1994 \\
7 & Physics & 2 & 19 & Dai Nianzu & 1995 \\
8 & Chemistry & 4 & Guo Zhengyi & 1995 \\
9 & Sciences of Earth & 5 & 59 & Tang Xiren & 1995 \\
10 & Comprehensive Works & 7 & 60 & Lin Wenzhao & 1995 \\
11 & General Index & 1 & Wang Youpeng & 1995 \\
\hline
\end{tabular}

In addition to the general preface and general notices for the whole series, an introduction for each of the ten parts outlines the history of the disciplines and prominent sources. Further introductory notes composed for 541 works included in the CS by around 100 scholars are of considerable academic significance. Were these introductions put together in one book they would make a one-million-character bibliographical guide to pre-1900 Chinese S\&T texts, showcasing research results in the history of science and technology in pre-modern China by the mid-1990s.

The master copies for the facsimile reprints mainly came from the collections of the library of the IHNS and that of the Shanghai Lexicographical Publishing House. The former is China's pre-eminent library dedicated to the history of science (now named the Li Yan Library), and holds about twenty-four hundred pre-modern Chinese books, of which three hundred are rare. The traditional Chinese bibliographic category of "masters and philosophers" forms about two-thirds of the total collection, and is especially strong in pre-modern mathematical books (about 660 copies). The Shanghai Lexicographic Publishing House inherited the rich collection left in Shanghai by Chung Hwa Book Co., Ltd., one of China's largest modern publishing enterprises before 1949.5 In addition, important texts from many other renowned institutions were reproduced in the series, such as from the National Library of China (NLC), Library of CAS, Peking University Library, Shanghai Library, Nanjing Library, Nanjing Museum, and Zhejiang Library.

4 Except for the three parts of Chemistry, Medicine, and General Index, chief editors for the other eight parts were all from the IHNS. Ren Jiyu, librarian of the National Library of China, was invited to be the editor-in-chief of the whole series.

5 Chung Hwa Book Co., Ltd. was founded in Shanghai in 1912, and relocated its headquarters to Beijing in 1954. It is now officially designated as Zhonghua Book Company in English. 
Mathematics, astronomy, agriculture, and medicine, which were more developed in pre-modern China, have individual categories in the traditional classification of the Four Branches, and an abundance of extant works. As physics, chemistry, and biology are modern concepts imported in the late nineteenth century, traditional texts on these subjects were selected from among scattered sources. In comparison with the largest comprehensive facsimile series of pre-modern books at the time, each of which includes over 3000 titles and uses the Four Branches system, the CS is especially strong in the two categories of mathematics and astronomy, far outnumbering its counterparts (Table 2).

Table 2: Comparison of four categories in different facsimile series

\begin{tabular}{|c|c|c|c|c|c|}
\hline & Total & Mathematics & Astronomy & Agriculture & Medicine \\
\hline $\begin{array}{c}\text { Compendium of Sources on Chinese Science and } \\
\text { Technology }(C S, 1993-1997)\end{array}$ & 541 & 90 & 82 & 43 & 26 \\
\hline Facsimile Reprint of Wenyuange Edition of the & & & & & \\
\hline $\begin{array}{c}\text { Complete Collection in Four Treasuries (hereafter } \\
\text { SKQS) (Yingyin Wenyuange Siku quanshu 景印 } \\
\text { 文渊阁四库全书, 1986) }\end{array}$ & 3461 & 25 & 31 & 10 & 97 \\
\hline $\begin{array}{c}\text { A Supplement to SKQS (Siku quanshu cunmu } \\
\text { congshu 四库全书存目丛书, 1997) }\end{array}$ & 4508 & 2 & 10 & 5 & 76 \\
\hline $\begin{array}{c}\text { A Sequel to SKQS (Xuxiu siku quanshu 续修四 } \\
\text { 库全书, 2002) }\end{array}$ & 5213 & 45 & 55 & 67 & 261 \\
\hline
\end{tabular}

The characteristics and important sources of each part of the CS are described below.

The Mathematics part is the largest in the CS, containing five volumes and ninety titles. The scope ranges from the Mathematical Canon of the Gnomon of the Zhou (Zhoubi suanjing 周髀算经) (ca. 1st century BCE) to the treatises of Li Shanlan 李善兰 (18111882), the most important late Qing mathematician. It covers the Han and Tang mathematical classics, masterpieces of the Song and Yuan mathematics zenith, applied mathematics of the Ming period, Qing scholars' works on classical Chinese mathematics, and so forth. The series also includes many books of the late Ming and early Qing dynasties (the seventeenth to eighteenth century) influenced by European mathematics, such as Essential Principles of Mathematics (Shuli jingyun 数理精蕴, 1723) and other influential compiled and translated works. Jihe yuanben 几何原本 (Books IVI and Books VII-XV first published in 1607 and 1857, respectively), the Chinese translation of Euclid's Elements, had important implications from the early seventeenth century, so the fifteen books jointly published in 1864 were reproduced and included as an appendix.

The CS embraces almost all the extant pre-seventeenth century mathematical works, a total of only thirty-six titles; from the seventeenth to the mid-nineteenth century, fiftyfour titles were selected from among hundreds of mathematical monographs. Attached to the end of this part is a "Bibliography of the Uncollected [Works]," listing about 1200 
titles written before 1912. The Mathematics part to this day remains the most practical collection of historical materials of mathematics in pre-modern China.

The compilation of this part benefited from the solid foundation laid by senior scholars such as Li Yan 李俨 (1892-1963), Qian Baocong 钱宝琮 (1892-1974), and Yan Dunjie 严敦杰 (1917-1988). Li Yan, the first director of the IHNS, excelled at the history of mathematics in pre-modern China, focusing on bibliographical research, and spent decades doggedly collecting and cataloguing old mathematical books. The IHNS library accommodates around five hundred pre-modern mathematical books donated by $\mathrm{Mr}$. Li, including around seventy pre-1900 Japanese wood-block books and manuscripts.

In terms of editions, sixteen manuscripts and thirty-three pre-1796 block prints, many of which are rare, provide the basis for the facsimile reprints (Liang 1995). A few instances are as follows:

The major pre-seventh century mathematical works are referred to as the Ten Works of Mathematical Classics (Suanjing shishu 算经十书). For six of them, such as the Mathematical Canon of the Gnomon of the Zhou and Nine Chapters on Mathematical Procedures (Jiuzhang suanshu 九章算术, hereafter Nine Chapters), Southern Song (1213) block-printed editions are available, the oldest extant editions of each book. In 1981, these editions were reproduced and published by the Cultural Relics Press. In comparison, the Mathematics part of the CS took a different approach by selecting the movable-type editions of the Printing Institute in the Qing Wuying Palace 武英殿 for seven classics. This edition of the Nine Chapters (ca. 1776), a critical edition by the renowned scholar Dai Zhen 戴震 (1724-1777), is more complete than the Song edition, half of which is missing. The CS even selected a special copy. It was stored in the Summer Palace at Chengde for Emperor Qianlong himself, and corrected a few typographical errors of the first print, and is now held in Nanjing Museum.

The manuscript of Excerpts and Prefaces from Various Mathematical Works (Zhujia suanfa ji $x$ u ji 诸家算法及序记) was copied from the Great Compendium of the Yongle Era (Yongle dadian 永乐大典), which collected many Song and Yuan rare mathematical historical materials, though the related volume of the original Great Compendium of the Yongle Era has been lost. The first facsimile reprint was made from a unique copy held at the IHNS.

The manuscript of The Precious Mirror of Mathematics (Suanxue baojian 算学宝鉴, by Wang Wensu 王文素) is representative of works on applied mathematics of the Ming period, with an author's preface of 1524, and was reproduced for the first time based on the unique copy at the NLC.

The early Qing manuscript of The Meaning of Methods for Alternation and Combination (Cuozong fayi 错综法义, by Chen Houyao 陈厚耀 [1648-1722]) forms part of the manuscript Exploring the Mystery of Mathematics (Suanyi tan'ao 算义探奥, also by Chen). 
Held at the IHNS, this unique book was the first Chinese work to explore permutation and combination, and was reproduced for the first time.

The block-printed edition of The Study of Vision (Shi xue 视学, by Nian Xiyao 年希尧) was first published in 1729 and enlarged in 1735. Large in size and full of exquisite woodcuts, it marks the first Chinese monograph studying the principles of perspective and European painting techniques. Part of it derives from Perspectiva Pictorum et Architectorum (1693) by the Italian Jesuit Andrea Pozzo (1642-1702). Eight copies can be found in Europe and only three in China. The Study of Vision was photocopied from the IHNS copy of the 1735 edition.

The Astronomy part comprises eighty-two titles in eight volumes. It centers on astronomy and calendrical science, as well as documents on astrology. Having long been monopolized by the imperial authorities, sciences of heaven in pre-modern China underwent a relatively independent development, while still being repeatedly affected by other civilizations. This part includes not only the astronomical and calendrical chapters in the "Official Dynastic Histories" (Zhengshi 正史), and a large number of private works, but also some drawn from India, West Asia, and Europe.

The early-eighth century Prognostication Classic of the Kaiyuan Reign Period (Kaiyuan zhanjing 开元占经, ca. 728), for instance, is a voluminous work on astrology compiled by Gautama Siddha, an Indian scholar serving in the Tang astronomical administration. In particular, it records early star catalogue data, and a Chinese translation of Jiuzhi li 九执历， a long-lost Indian astronomical treatise. The late Ming Dadetang 大德堂 manuscript at the NLC is the master copy for this book.

In 1383, the Ming founder Zhu Yuanzhang 朱元璋 (1328-1398) decreed the production of a Chinese translation of the Introduction to Astrology (Tianwen shu 天文书) by the Persian mathematician and astronomer Kūshyār ibn Labbān (fl. 1000). The blockprinted edition ordered by the emperor in the late fourteenth century is the basis for the reproduction here.

The mid-seventeenth century New Treatises on Calendrical Astronomy from Europe (Xiyang xinfa lishu 西洋新法历书), in effect a large book series, can be seen as a crucial result of Sino-Western scientific exchanges in the early modern period. Under the collaborative compilation and translation of Jesuits, including Johann Adam Schall von Bell (1591-1666), and Chinese scholars, it introduced from Europe astronomical theories and applied knowledge based on the Tychonic System, and was made the foundation of Qing official astronomy, exerting far-reaching influence in East Asia. The CS reproduces the Shunzhi and Kangxi (mid-seventeenth century) block-printed editions from Peking University Library and Shanghai Library. Sixteen treatises are included among the total of around thirty, and the facsimile reprint numbers one thousand pages.

The Astronomy part collects a few unearthed documents that were from major 
archaeological discoveries in the twentieth century, spanning astronomical data found on the oracle bones from the Ruins of Yin (ca. 1300-1027 BCE), the silk book Miscellaneous Astronomical and Meteorological Prognostications (Tianwen qixiang zazhan 天 文气象杂占) found at Mawangdui 马王堆, Prognostications of the Five Planets (Wuxing zhan 五星占), bamboo strips of Han almanacs, and almanacs from Dunhuang and Turfan.

For rare books, Tonghu loujian zhidu 铜壸漏箭制度 (1247, by Yan Yizhong 颜監仲) and Zhunzhai xinzhi jilou tushi 准斋心制几漏图式 (ca. 1281, by Sun Fengji 孙逢吉), on clepsydras/water-clocks, are of immense importance for researching the development of water-clocks and the technologies and systems of timing of the mediaeval period. The CS contains the manuscript (1823, stored in the NLC) prepared by the famous bibliophile Huang Pilie 黄不烈 (1763-1825), a unique copy reproduced for the first time.

The Agriculture part (five volumes, forty-three titles) contains valuable agricultural treatises from all periods. It covers comprehensive agricultural works, regional ones, as well as those on natural history, sericulture, animal husbandry, famine relief, and locust control. The most influential titles include Essential Techniques for the Common People (Qimin yaoshu 齐民要术), Wang Zhen's Agricultural Treatise (Wang Zhen nongshu 王祯农书), and Complete Treatise on Agriculture Administration (Nongzheng quanshu 农政 全书).

The Biology part (three volumes, forty-two titles) is dominated by works of natural history, such as Quanfang beizu 全芳备祖 (a thesaurus of botany) and Illustrated Research on the Names and Facts of Plants (Zhiwu mingshi tukao 植物名实图考). This part also includes a critical edition of the Western Han silk book Classic of Horse Physiognomy (Xiang ma jing 相马经) from Mawangdui. The first Chongzhen edition of Zhuzuotang ji 著作堂集 (1642), an insect fauna of Jiaxing, is exceedingly rare, and was reproduced from the NLC copy for the first time. The Agriculture and Biology parts are complementary and overlap to a certain degree.

Since 1949, specialized research and publishing institutions for traditional Chinese medicine (TCM) have published more than twenty facsimile series of pre-modern books on TCM, gathering together over one thousand old books (Nan and Jia 2016, 661-692). Thus, the Medicine part (seven volumes, twenty-six titles) has relatively few titles, and only includes those of widespread popularity. Seven of them were reproduced from Ming and Qing block-printed editions, and the remainder were reprinted based on the Facsimile Reprint of Wenyuange Edition of SKQS.

The Technology part (five volumes, seventy-three titles) highlights historically essential texts on engineering and craftsmanship (some are excerpts). It covers a wide spectrum of fields: water engineering (twenty-nine titles), military technology 
(twenty-five titles), architecture (five titles), machinery (four titles), mining and metallurgy (three titles), shipbuilding (two titles), textiles (one title), and printing (one title).

The following two cases exemplify the rare books in this part.

Between 1041 to 1048, Bi Sheng 毕昇 invented clay movable-type printing. However, later generations rarely utilized clay type, mainly relying on those made of wood and metal. In the first half of the nineteenth century, Zhai Jinsheng 翟金生 produced clay types, hundreds of which are now at the IHNS, to print books by Bi's method. In 1844, his collection of personal poems was published as First Collection by Experimental Printing with Clay Types (Niban shiyin chubian 泥版试印初编), recording this special craft experiment, though very few copies are extant. The reproduction in this part stems from the NLC collection.

In the late Ming period, the high-official and Catholic Sun Yuanhua 孙元化 (15821632) was aided by the Portuguese to train artillery troops to use against the invading armies of the Later Jin (1616-1636, renamed afterwards as the Qing). Sun compiled a treatise On Western Firearms (Xifa shenji 西法神机), part of which derived from latesixteenth- and early-seventeenth-century Spanish artillery works. However, it was eventually only published in 1902, and only four copies are known to have survived. This first facsimile reprint in the CS uses the IHNS copy.

The Physics part (two volumes, nineteen titles) is primarily composed of famous books on optics, acoustics, and music, such as Master Mo (Mo Zi 墨子), Collected Works on Music and Pitch-Pipes (Yuelü quanshu 乐律全书, ca. 1600), and Jingjing lingchi 镜镜詅 痴 (a book on geometrical optics, 1835).

Over half of the works in the Chemistry part (two volumes, forty-seven titles) are on alchemy, reprinting the 1930s facsimile edition of the Depository of Taoist Scriptures (Dao zang 道藏) of the Ming period. The remaining books are mostly of short length, and pertain to wine, sugar, incense, ink, varnish, well salt, pottery, fireworks, and many other aspects.

The Sciences of Earth part (five volumes, fifty-nine titles) ranges from geology and geography to meteorology, hydrology, and maps. Geography, travels to border and foreign areas, and several pre-modern maps are selected among more common sources, such as Commentaries on the Classic of Waterways (Shuijing zhu 水经注), Diary of the Travels of Xu Xiake (Xu Xiake youji 徐霞客游记), and the so-called Chart of Zheng He's Maritime Voyages (Zheng He hanghai tu 郑和航海图).

Another undertaking in this field should be particularly noted. In 1983, Cao Wanru 曹婉如 and others at the IHNS initiated the compilation of An Atlas of Ancient Maps in China (Zhongguo gudai dituji 中国古代地图集), three voluminous books which were published by the Cultural Relics Press: Warring States to Yuan (1990), Ming (1995), and 
Qing (1997). These volumes reproduced 659 pre-modern rare maps from the Warring States period to the early Qing, most for the first time. The captions and notes for the maps are coupled with English translations, and the appended research papers in each volume contains English abstracts.

The Comprehensive Works part (seven volumes, sixty titles) includes texts that are multi-disciplinary, or reflect the history of scientific thought and social history (some are excerpts). To cite a few examples, classics are represented by the Book of Historical Documents (Shangshu 尚书) and Master Lao (Laozi 老子), general cyclopedia (leishu 类书) by Imperially Inspected Anthology of the Taiping Era (Taiping yulan 太平御览), famous miscellanea by Mengxi bitan 梦溪笔谈, and masterpieces by The Exploitation of the Works of Nature (Tiangong kaiwu 天工开物) and Biographies of Astronomers and Mathematicians (Chouren zhuan 畴人传).

In addition to a general catalogue, an index of author names and of book titles, the General Index part provides a subject catalogue of the traditional classification of the Four Branches, which embodies the conceptual changes of disciplines from past to present times, apart from a chronology of the history of science and technology in premodern China.

The restraints of the time made it difficult for the CS series to obtain all the best editions for reproduction. In particular, almost no use was made of rare books kept overseas. The introductory notes at the beginning of each title, having been written by a hundred authors, are somewhat inconsistent in style, and some notes make no mention of the editions and sources for the original copies of facsimile reprints.

Since the 1990s, the IHNS has initiated a number of further large academic publication projects, such as hosting the compilations of History of Science and Technology in Pre-modern China (Zhongguo kexue jishu shi 中国科学技术史, 26 vols., 1998-2011), Complete Collection of Traditional Chinese Arts and Crafts (Zhongguo chuantong gongyi quanji 中国传统工艺全集, 20 vols., 1996-2016), and Series of Studies in the History of SET in Modern China (Zhongguo jinxiandai kexue jishu shi yanjiu congshu 中国近现代科学技术史研究从书, 36 titles, 2004-2009), as well as organizing the translation of the Science and Civilisation in China series founded by Joseph Needham (Chinese translations in 14 vols., 1990-2018). ${ }^{6}$ The CS was one among such projects.

The period from 2000 to 2020 has witnessed dramatic changes with regard to Chinese historical materials. Large quantities of facsimile reprints of pre-modern books provide access to vastly more research materials. The prevalence of digitization brings

6 For reviews of History of Science and Technology in Pre-modern China and Complete Collection of Traditional Chinese Arts and Crafts, see Dai (2019), and Zhang et al. (2020). 
unprecedented convenience. ${ }^{7}$ Yet, despite this, the CS remains the only comprehensive large-scale collection of historical materials on science and technology in pre-modern China, irreplaceable even to this day, many parts of which are still routinely referred to by those in the field. ${ }^{8}$

\section{Acknowledgments}

The author would like to extend his gratitude to Mr. Guo Shuchun, Ms. Jiang Lirong, and Mr. Zeng Xiongsheng for sharing their experiences of participation in the project of the $C S$, and to the anonymous reviewers for their valuable suggestions.

\section{References}

Compilation Committee. 2012. Zhongguo guji zongmu: Jing bu 中国古籍总目 - 经部 [General Catalogue of Pre-modern Chinese Books: Classics]. Beijing: Zhonghua Book Company.

Dai, Wusan. 2019. "Epitome of Research on the History of Science and Technology in China: A Review of the Book Series History of Science and Technology in Pre-modern China in Comparison with Needham's Science and Civilisation in China." Chinese Annals of History of Science and Technology 3 (1): 87-99.

Editorial Committee. 1989-1998. Zhongguo guji shanben shumu 中国古籍善本书目 [Union Catalogue of Rare Books in China]. Shanghai: Shanghai Classics Publishing House.

Liang, Zongju 梁宗巨. 1995. “Zhongguo shuxue shiliao de yuansou: Zhongguo kexue jishu dianji tonghui: Shuxue juan pingjie" 中国数学史料的洲薮——中国科学技术典籍通汇・数学卷》评介 [The "Deep Lake" of Historical Materials of Mathematics in China: A Review on Compendium of Sources on Chinese Science and Technology: Mathematics]. Chuantong wenhua yu xiandaihua 传统文 化与现代化 [Chinese Culture: Tradition and Modernization], no. 1, 93-95.

Nan, Jiangtao 南江涛. 2012. "Xinzhongguo chengli yilai xinbian guji congshu chuban zongshu” 新中国成立以来新编古籍从书出版综述 [A Review of the Publications of Newly Compiled Pre-modern Books Series since 1949]. Chuban shiliao 出版史料 [Publication Archives], no. 3, 73-78.

7 At present, the largest free database, the Repository of Pre-modern Books of China (Zhonghua guji ziyuanku 中华古籍资源库) provides the full images of more than 33,000 copies mainly from the NLC. See the website: http://www.nlc.cn/pcab/zy/zhgj_zyk/ (accessed April 9, 2021).

8 The compilation and publication of books on science and technology in pre-modern China have recently led to new approaches. This is particularly evident in the wide usage of overseas collections, and the improvements in reproduction and editing. For example, from 2014 to 2020, Selected Sources on Science and Technology in Pre-modern China (Zhongguo keji dianji xuankan 中国科 技典籍选刊), hosted by the IHNS, has been published by Hunan Science and Technology Press in four parts and fifteen titles. Rare books at home and abroad are photocopied in high definition, and facsimile reprints and critical editions are integrated. As well as including introductions and appendices, the images of each page of the original copies and the transcribed texts with critical apparatus are routinely placed side-by-side for the convenience of researchers. Thus, the best and rarest editions are disseminated, while reflecting the latest research results. 
Nan, Jiangtao, and Jia Guirong 贾贵荣. 2016. Xinzhongguo guji yingyin congshu zongmu 新中国古 籍影印丛书总目 [A Catalog of the Facsimile Series of Chinese Ancient Books since 1949]. Beijing: National Library of China Publishing House.

Ren, Jiyu 任继愈, ed. [1993-1995] 2015. Zhongguo kexue jishu dianji tonghui 中国科学技术典籍通 汇 [Compendium of Sources on Chinese Science and Technology]. Zhengzhou: Elephant Press.

Sun, Xianbin. 2017. "Review on the Collation of Premodern Chinese Sources on Science and Technology." Chinese Annals of History of Science and Technology 1 (2): 113-131.

$\mathrm{Wu}, \mathrm{Ge}$ 吴格. 2016. “Qianyan” 前言 [Preface]. In Xinzhongguo guji yingyin congshu zongmu, edited by Nan Jiangtao and Jia Guirong. Beijing: National Library of China Publishing House.

Zhang, Yan, Bai Yunyan, Shen Zhixian, et al. 2020. "Complete Collection of Traditional Chinese Arts and Crafts (Zhongguo chuantong gongyi quanji 中国传统工艺全集): A Work of Ingenuity.” Chinese Annals of History of Science and Technology 4 (1): 166-174. 